\title{
STRESOGENNOŚĆ PRACY PRZEDSIĘBIORCY W OCENIE STUDENTÓW - WYNIKI BADAŃ PILOTAŻOWYCH
}

\begin{abstract}
W artykule zaprezentowano wybrane wyniki badań pilotażowych, które dotyczyły postaw przedsiębiorczych studentów. W opracowaniu punkt ciężkości położono na postrzeganie pracy przedsiębiorcy jako czynnika mogącego kształtować zamiar podjęcia własnej działalności gospodarczej. Przyjęty przez Autorki model badawczy zakładał, że na powstanie intencji przedsiębiorczej wpływa wiele czynników. Jednym z nich jest postrzeganie przyszłej pracy. Jako czynniki, które potencjalnie mogą kształtować postawę przedsiębiorcza, przyjęto stresogenność działań podejmowanych przez przedsiębiorcę oraz zakres kontroli nad pracą. Za jeden z głównych celów badania przyjęto także ocenę stopnia stresowości działań podejmowanych przez przedsiębiorcę oraz identyfikację związku pomiędzy dokonaną oceną a kształtowaniem się postaw przedsiębiorczych, mierzonych zamiarem podjęcia w przyszłości działalności gospodarczej. Dodatkowym celem badania było również przeprowadzenie oceny wpływu postrzeganego zakresu kontroli nad pracą na prezentowane przez studentów intencje przedsiębiorcze. Uzyskane w efekcie przeprowadzonych badań pilotażowych wyniki wskazuja, że dla badanej grupy studentów wszystkie ze wskazanych cech pracy przedsiębiorcy mogą mieć potencjalnie charakter stresogenny, co jednak nie ma istotnego znaczenia $\mathrm{z}$ punktu widzenia prezentowanych przez nich postaw przedsiębiorczych. W przeprowadzonym badaniu pilotażowym wykazano również, że dla respondentów wysoki zakres kontroli jaką przedsiębiorca może sprawować nad własną pracą stanowi czynnik zachęcający do podejmowania w przyszłości działalności gospodarczej. Jednak także w tym wypadku jedynie dla dwóch z pięciu badanych czynników zmienną różnicującą okazały się postawy przedsiębiorcze.
\end{abstract}

Słowa kluczowe: stres w pracy, zakres kontroli, postawy przedsiębiorcze, przedsiębiorczość

\section{WPROWADZENIE}

Wraz ze zmianą systemu gospodarczego w Polsce radykalnie zmieniły się liczba i struktura własnościowa przedsiębiorstw. Według danych GUS na koniec roku 2011 w systemie REGON zarejestrowanych było 3869897 podmiotów, z czego 3748026 $\mathrm{z}$ nich to podmioty gospodarki narodowej działające $\mathrm{w}$ sektorze prywatnym ${ }^{3}$. Oznacza to, że w Polsce jest 31-krotnie więcej podmiotów prywatnych niż publicznych. Prywatni przedsiębiorcy, w zależności od wielkości przedsiębiorstwa, nie tylko tworzą miejsca pracy dla siebie i swoich najbliższych (przedsiębiorstwa rodzinne), ale także setek tysięcy

\footnotetext{
${ }^{1}$ Dr Anna Walczyna, Katedra Ergonomii, Wydział Zarządzania, Politechnika Lubelska, ul. Nadbystrzycka 38, 20-618 Lublin, tel. 08153845 22, e-mail: a.walczyna@pollub.pl (autor korespondencyjny)

${ }^{2}$ Dr Anna Arent, Katedra Zarządzania, Wydział Zarządzania, Politechnika Lubelska, ul. Nadbystrzycka 38, 20 618 Lublin, e-mail: a.arent@pollub.pl

${ }^{3}$ http://www.stat.gov.pl/cps/rde/xbcr/gus/f_polska_w_liczbach_2012.pdf.
} 
rodaków. W 2010 roku to głównie przedsiębiorcy stworzyli ponad 600 tys. miejsc pracy ${ }^{4}$. Według tego samego źródła w sektorze prywatnym pracuje czterokrotnie więcej ludzi niż w publicznym ${ }^{5}$. Pracodawcy prywatni odgrywają więc niebagatelną rolę $\mathrm{w}$ kreowaniu rynku pracy. $Z$ tego też powodu, a także ze względu na znaczenie sektora prywatnego (zwłaszcza mikro-, małych i średnich firm) w tworzeniu PKB tak duże znaczenie odgrywa wspomaganie tworzenia nowych podmiotów gospodarczych, a więc kreowanie postaw przedsiębiorczych.

\section{POSTAWY PRZEDSIĘBIORCZE}

Termin ,postawa” jest pojęciem złożonym, wyrażającym - najogólniej mówiąc - „gotowe i trwałe ustosunkowania do konkretnych osób i obiektów"6. Ustosunkowanie to podlega kształtowaniu zarówno w wyniku aktywności własnej podmiotu, jak też oddziaływania innych osób i grup. Postawa zawsze jest czyjaś, skierowana na jakiś obiekt lub ich grupę i jako taka oznacza względnie trwałą skłonność do pozytywnego lub negatywnego wartościowania przedmiotu postawy przez jej nosiciela. Tak więc postawa ma jakiś znak (pozytywny vs negatywny), a także określone natężenie. Jak wskazuje Wojciszke, postawy charakteryzują się także innymi właściwościami, takimi jak: ważność, wewnętrzna zgodność i stopień powiązania z innymi postawami ${ }^{7}$. Często $\mathrm{w}$ literaturze wskazuje się także na złożoność postaw, obejmującą komponent emocjonalny (uczuciowooceniający), poznawczy (wiedza, przekonania na temat obiektu postawy) i behawioralny (skłonność do określonego zachowania) ${ }^{8}$. Te trzy elementy tworzą trójczłonowy model, który można zastosować do analizy postaw przedsiębiorczych. Składają się na nie czynniki poprzedzające (wartości, potrzeby, chęci, przekonania, zwyczaje danej osoby), intencje i działania przedsiębiorcze ${ }^{9}$. Trzeba przy tym podkreślić, że kształtowanie postawy wobec podejmowania własnej działalności gospodarczej jest efektem uzyskanych doświadczeń, w tym dotychczasowego przebiegu edukacji i kariery zawodowej ${ }^{10}$. W pierwszym wypadku ważną rolę odgrywa szkoła wyższa. Oddziaływanie to może być powiązane zarówno z poziomem wykształcenia (ukończone studia lub studiowanie na określonym poziomie), jak i studiowanym kierunkiem. Obydwa czynniki wpływają na posiadane kompetencje stricte zawodowe, prowadząc jednocześnie do uzyskania tych o bardziej uniwersalnym

\footnotetext{
${ }^{4}$ Polska Konfederacja Pracodawców Prywatnych LEWIATAN, Przedsiębiorcy w Polsce. Fakty, liczby, przykłady, Warszawa, Grudzień 2012, s. 4.

${ }^{5}$ Ibidem.

${ }^{6}$ B. Wojciszke, Człowiek wśród ludzi. Zarys psychologii społecznej, Wydawnictwo Naukowe SCHOLAR, Warszawa 2002, s. 178.

${ }^{7}$ Ibidem, s. $180-181$.

${ }^{8}$ Ibidem, s. 181; M. Marody, Sens teoretyczny a sens empiryczny pojęcia postawy. Analiza metodologiczna zasad doboru wskaźników w badaniach nad postawami, PWN, Warszawa 1976, s. 14; E. Aronson, T.D. Wilson, R.M. Akert, Psychologia spoteczna: serce i umyst, Zysk i S-ka, Poznań 1997, s. 314; P.G. Zimbardo, M.R. Leippe, Psychologia zmiany postaw $i$ wpływu społecznego, tłum. P. Kwiatkowski, Zysk i S-ka, Poznań 2004, s. 52; S.A. Rathus, Psychologia wspótczesna, tłum. B. Wojciszke, Gdańskie Wydawnictwo Psychologiczne, Gdańsk 2004, s. 769.

${ }^{9}$ A. Kurczewska, Przedsiębiorczość jako proces współoddziaływania sposobności i intencji przedsiębiorczych, PWN, Warszawa 2013, s. 134-135.

${ }^{10}$ Warto zauważyć, że wiedza i wynikające z niej przekonania mogą mieć charakter zarówno obiektywny, naukowy, znajdujący potwierdzenie w faktach, jak też potoczny, oparty na wybiórczych doświadczeniach czy mitach funkcjonujących w danej społeczności.
} 
charakterze, w tym również społecznych. Tworzenie inkubatorów przedsiębiorczości oraz biur karier przy uczelniach także może pozytywnie wpływać na postawy proprzedsiębiorcze, w tym intencje przedsiębiorcze.

W wykształcaniu się postaw przedsiębiorczych istotne znaczenie mają również czynniki o charakterze indywidualnym, takie jak płeć, wiek oraz doświadczenia czy tradycje rodzinne związane z działalnością przedsiębiorczą w najbliższej rodzinie.

\section{PRZEDSIĘBIORCA I JEGO PRACA}

Istotną składową postaw wobec przedsiębiorczości wydają się obraz pracy przedsiębiorcy, wyobrażenie jej specyfiki, wymagań i wyzwań z nią związanych. Próbując określić sytuację przedsiębiorcy, należy najpierw odpowiedzieć na pytanie, kim on jest. Przedsiębiorca to właściciel przedsiębiorstwa i jego menedżer - często zatrudnia pracowników, jest jednocześnie organizatorem i koordynatorem zasobów ekonomicznych, dokonuje wyboru alternatywnych zastosowań różnych zasobów, a w konsekwencji ponosi ryzyko działalności. Biorąc pod uwagę tempo zmian zachodzących w otoczeniu, przedsiębiorca powinien być także innowatorem, dostrzegać i wykorzystywać okazje. Dodatkowo, podejmuje ryzyko i ponosi wszystkie jego konsekwencje ${ }^{11}$. Nawiązując do klasycznej koncepcji funkcji kierowniczych (planowanie, organizowanie, przewodzenie i kontrolowanie), można powiedzieć, że nie wyczerpują one obowiązków i odpowiedzialności przedsiębiorcy. Stąd w literaturze przedmiotu dużo mówi się o cechach przedsiębiorcy, których posiadanie warunkuje skuteczne realizowanie funkcji, wskazywanych w wymienionych definicjach. Cechy te, zdaniem części autorów, mają wrodzony charakter, inni twierdzą, że podlegają kształceniu. Ich katalog jest szeroki. Często wymienia się te o charakterze psychologicznym, takie jak: wiara w siebie, optymizm, zdecydowanie, wysoki poziom energii, wysoka potrzeba osiagnięć, samosterowność, umiarkowana skłonność do ryzyka ${ }^{12}$. Inne cechy to odpowiedzialność, potrzeba autonomii, inicjatywa, wytrwałość, umiejętność utrzymywania kontaktów międzyludzkich, asertywność i umiejętności komunikacyjne, samoświadomość emocjonalna, samokontrola, samomotywacja, cierpliwość, obsesja poszukiwania okazji, zdolność do promowania innowacji, stosunek do zmian ${ }^{13}$. Biorąc pod uwagę specyfikę pracy przedsiębiorcy, do wymienionych cech, których posiadanie wydaje się pożądane, należy również dodać odporność na stres. Stres w pracy przedsiębiorcy łączy się z wielością pełnionych funkcji. Wychodząc z modelu Coopera, źródła stresu wiążą się ze specyfiką pracy, rolami w organizacji, stosunkami w pracy i rozwojem kariery, strukturą i klimatem organizacji oraz stykiem praca-dom ${ }^{14}$. Ze względu na wielość branż, w których działają małe i średnie przedsiębiorstwa, trudno charakteryzować czynnik definiowany jako nieodłącznie zwią-

\footnotetext{
${ }^{11}$ Przytoczony zestaw cech odnoszących się do przedsiębiorcy jest podstawą tworzenia definicji przedsiębiorcy. Przeglądu dokonano na podstawie: T. Piecuch, Przedsiębiorczość. Podstawy teoretyczne, C.H. Beck, Warszawa 2010 , s. 58

${ }^{12}$ S.P. Robbins, D.A. DeCenzo, Podstawy zarzqdzania, PWE, Warszawa 2002, s. 164.

${ }^{13}$ Por. M. Laszczak, Kierowanie mata firmq. Tajniki przedsiębiorczości, Poltext, Warszawa 2004, s. 43-45; Mikroprzedsiębiorstwa: sytuacja ekonomiczna, finansowanie, wtaściciele, red. E. Balcerowicz, CASECentrum Analiz Społeczno-Ekonomicznych, Warszawa 2002, s. 101; F. Bławat, Przedsiębiorca $w$ teorii przedsiębiorczości i praktyce małych firm, Gdańskie Towarzystwo Naukowe, Gdańsk 2003, s. 50-56.

${ }^{14}$ Europejska Agencja Bezpieczeństwa i Zdrowia w Pracy, Badania nad stresem w pracy, Luksemburg 2006, s. 44.
} 
zany z praca. Pozostałe stresory mają, najogólniej mówiąc, charakter społeczny ${ }^{15}$. Istotnym czynnikiem generującym stres mogą być między innymi role odgrywane w organizacji, a w zasadzie ich konflikt oraz trudność z jednoznacznym zdefiniowaniem. Osoby prowadzące jednoosobową działalność gospodarczą pełnią w swoich przedsiębiorstwach wszelkie możliwe funkcje: jako właściciele ponoszą wszystkie konsekwencje podejmowanych decyzji i działań, są jednocześnie menedżerami i wykonawcami, muszą uwzględniać wymagania odbiorców/klientów, kontrahentów, organów nadzorczych i skarbowych. Podnoszona przez przedsiębiorców nadmierna zmienność oraz niejednoznaczność i zawiłość obowiązujących przepisów prawa ${ }^{16}$ mogą być przyczyną stresu związanego $\mathrm{z}$ niejednoznacznością roli. W wypadku prowadzenia mikroprzedsiębiorstwa lub samozatrudnienia przedsiębiorcy mogą być narażeni na stres związany z przeciążeniem lub niedociążeniem roli, co z kolei może generować stres na styku praca-dom. Dla wielu przedsiębiorców istotnym stresorem może być też rozwój kariery zawodowej, chociaż w Badaniu Kapitału Ludzkiego z roku 2012 tylko 15\% respondentów wskazywało na chęć rozszerzenia działalności, a aż $80 \%$ ankietowanych przedsiębiorców deklarowało prostą kontynuację prowadzonej aktualnie działalności ${ }^{17}$. Nie wiadomo jednak, w jakim stopniu deklaracje o kontynuacji działalności wynikały z postrzeganych przez nich barier ${ }^{18}$. Wymieniony stresor $w$ rzeczywistości może więc mieć o wiele większy zasięg.

$\mathrm{Z}$ punktu widzenia prezentowanych badań istotnym modyfikatorem wpływającym na postrzeganie stresogenności pracy, w tym pracy przedsiębiorcy, jest zakres kontroli. Zgodnie z modelem Karaska - oprócz wymagań i wsparcia społecznego ${ }^{19}$ - to jeden $\mathrm{z}$ trzech predyktorów stresu. Wymienione czynniki wchodzą ze sobą w interakcje, powodując określony poziom stresu - najwyższy w sytuacji wysokich wymagań i przy jednoczesnym braku kontroli nad pracą i wsparcia ${ }^{20}$.

\section{CHARAKTERYSTYKA BADAŃ I OSÓB BADANYCH}

Przedstawione założenia stały się przedmiotem badań pilotażowych. Ich celem była ocena stresowości pracy przedsiębiorcy oraz identyfikacja związku pomiędzy dokonaną oceną a kształtowaniem się postaw przedsiębiorczych, mierzonych zamiarem podjęcia własnej działalności gospodarczej dla wybranej grupy badanych. Jako dodatkowy cel przyjęto również ocenę wpływu postrzeganego zakresu kontroli nad pracą na prezentowane intencje przedsiębiorcze.

Badania przeprowadzono w okresie maj-czerwiec 2013 roku wśród 165 studentów ostatniego semestru studiów I i II stopnia kierunków zarządzanie oraz zarządzanie i inżynieria produkcji. Próba miała charakter wyczerpujący, a jej dobór był celowy. Wybrano studentów tych kierunków prowadzonych w Politechnice Lubelskiej, którzy w związku z programem studiów (ekonomia, finanse, zarządzanie zasobami ludzkimi,

\footnotetext{
${ }^{15}$ Por. A. Jachnis, Psychologia organizacji. Kluczowe zagadnienia, Difin, Warszawa 2008, s. 124-126.

${ }^{16}$ S. Czarnik, K. Turek, Wyksztatcenie, praca, przedsiębiorczość Polaków. Na podstawie badań zrealizowanych w 2012 roku w ramach III edycji projektu Bilans Kapitatu Ludzkiego, Polska Agencja Rozwoju Przedsiębiorczości, Warszawa 2012, s. 53.

${ }^{17}$ S. Czarnik, K. Turek, op. cit., s. 12.

${ }^{18}$ Ibidem, s. 53.

${ }^{19}$ Ze względu na przedmiot badań zbadanie wsparcia społecznego nie było możliwe.

${ }^{20}$ R. Cieślak, M. Widerszal-Bazyl, Psychospołeczne warunki pracy. Podręcznik do kwestionariusza, CIOP, Warszawa 2000, s. 12.
} 
zarządzanie strategiczne itp.) powinni nabyć kompetencji przydatnych w prowadzeniu działalności gospodarczej. Przyjęto także założenie, że powinno się to przełożyć na bardziej pozytywną postawę wobec przedsiębiorczości. Ponadto studenci studiów II stopnia odbyli kurs z zakresu stresu zawodowego i organizacyjnego, co powinno zwiększyć ich świadomość w tym zakresie. Ponieważ jednak ocena poznawcza barier związanych z rozwojem przedsiębiorczości jedynie w kategorii stresorów (wymagania) bez uwzględnienia wyzwań (wysoki zakres kontroli) może wspomnianą już pozytywną postawę osłabiać, postanowiono bliżej się przyjrzeć także temu aspektowi. Innym czynnikiem, różnicującym zarówno postawę wobec przedsiębiorczości, jak i ocenę pracy przedsiębiorcy w kategorii stresorów, mogą być dotychczasowe doświadczenia zawodowe. Dlatego też zdecydowano się na przeprowadzenie badań wśród studentów dwóch różnych form studiów (stacjonarnych i niestacjonarnych).

Do oceny postaw studentów wobec podejmowania działalności gospodarczej użyto kwestionariusza składającego się z trzech części. Pierwszą stanowił skorygowany kwestionariusz ankietowy, który posłużył do identyfikacji i oceny postaw studentów austriackich $^{21}$. Część druga skonstruowana została na podstawie skal W i K kwestionariusza „Psychospołeczne Warunki Pracy” ${ }^{22}$ i miała na celu ocenę przez ankietowanych poziomu stresogenności pracy przedsiębiorcy oraz zakresu kontroli nad pracą jako czynnika zachęcającego do podjęcia działalności gospodarczej. Część trzecią stanowiła metryczka kwestionariusza. Oprócz cech typowych, to znaczy wieku, płci, studiowanego kierunku, zawierała także pytania o tradycje rodzinne w zakresie przedsiębiorczości. Wyniki przedstawione w artykule opracowano na podstawie drugiej i trzeciej części kwestionariusza.

Strukturę badanej grupy pilotażowej z punktu widzenia przyjętych cech przedstawiono w tabeli 1.

Tabela 1. Struktura grupy pilotażowej według kryterium płci, wieku, poziomu, formy i kierunku studiów

\begin{tabular}{|c|c|c|c|c|}
\hline \multirow{2}{*}{ Lp. } & \multirow{2}{*}{ Cecha } & \multirow{2}{*}{ Kategoria cechy } & \multicolumn{2}{|c|}{ Respondenci } \\
\hline & & & $\mathbf{N}$ & $(\%)$ \\
\hline \multirow{3}{*}{1} & \multirow{3}{*}{ Płeć } & Kobieta & 102 & 61,8 \\
\hline & & Mężczyzna & 63 & 38,2 \\
\hline & & Ogółem & 165 & 100 \\
\hline \multirow{5}{*}{2} & \multirow{5}{*}{ Wiek } & $\leq 22$ lata & 82 & 49,7 \\
\hline & & $23-25$ lat & 41 & 24,8 \\
\hline & & $\geq 26$ & 41 & 24,8 \\
\hline & & Brak danych & 1 & 0,7 \\
\hline & & Ogółem & 164 & 100 \\
\hline \multirow{3}{*}{3} & \multirow{3}{*}{$\begin{array}{l}\text { Tradycje rodzinne w prowadzeniu } \\
\text { działalności gospodarczej }\end{array}$} & Tak & 107 & 64,8 \\
\hline & & Nie & 57 & 34,5 \\
\hline & & Ogółem & 164 & 100 \\
\hline \multirow{3}{*}{4} & \multirow{3}{*}{ Poziom studiów } & Studia I stopnia & 107 & 64,8 \\
\hline & & Studia II stopnia & 58 & 35,2 \\
\hline & & Ogółem & 165 & 100 \\
\hline
\end{tabular}

${ }^{21}$ E.J. Schwarz, M.A. Wdowiak, D.A. Almer-Jarz, R.J. Breitenecker, The effects of attitudes and perceived environment conditions on students' entrepreneurial intent. An Austrian perspective, „Education + Training” 51/4 (2009), s. 276-278.

${ }^{22}$ R. Cieślak, M. Widerszal-Bazyl, op. cit., s. 13; kwestionariusz „Psychospołeczne Warunki Pracy” dostępny na stronie: http://www.zus.pl/files/dpir/20081201_Ocena_obciazenia_zal2.pdf. 


\begin{tabular}{|c|l|l|c|c|}
\hline \multirow{2}{*}{5} & \multirow{2}{*}{ Forma studiów } & Studia stacjonarne & 98 & 59,4 \\
\cline { 3 - 5 } & & Studia niestacjonarne: & 67 & 40,6 \\
\cline { 3 - 5 } & & Ogółem & 165 & 100 \\
\hline \multirow{2}{*}{6} & \multirow{2}{*}{ Kierunek studiów } & Zarządzanie & 107 & 35,2 \\
\cline { 3 - 6 } & & $\begin{array}{l}\text { Zarządzanie i inżynieria } \\
\text { produkcji }\end{array}$ & 165 & 64,8 \\
\cline { 3 - 5 } & Ogółem & 100 \\
\hline
\end{tabular}

Źródło: opracowanie własne na podstawie wyników przeprowadzonych badań.

Podsumowując, badani to najczęściej kobiety $(61,8 \%)$, studenci studiów I stopnia $(64,8 \%)$, kierunku zarządzanie i inżynieria produkcji $(64,8 \%)$, odbywający studia w trybie stacjonarnym $(59,4 \%)$ oraz osoby poniżej 23 roku życia $(49,7 \%)$.

Wśród badanej grupy studentów zamiar podjęcia własnej działalności gospodarczej wyraziły 43 osoby $(26,1 \%)$, przy czym przeważająca część osób wskazała, że założenie własnej firmy nastąpiłoby jeszcze podczas studiów lub tuż po ich zakończeniu. Porównanie uzyskanych wyników $\mathrm{z}$ innymi badaniami ${ }^{23}$ pozwala na stwierdzenie, że pozytywną postawę przedsiębiorczą $\mathrm{w}$ badanej grupie wykazuje większy odsetek osób niż przeciętne w Polsce, planowany termin założenia firmy zaś jest krótszy.

Omawiana grupa respondentów to przede wszystkim mężczyźni, osoby do 25 roku życia oraz studenci o tradycjach rodzinnych w zakresie przedsiębiorczości. W grupie tej dominowały osoby kształcące się na studiach II stopnia, stacjonarnych, na kierunku zarządzanie.

\section{WYNIKI BADAŃ}

Stresogenność poszczególnych aspektów pracy przedsiębiorcy badane osoby oceniały na pięciostopniowej skali, gdzie liczba „1” oznaczała, że dany stresor zdecydowanie nie odnosi się do pracy przedsiębiorcy, a liczba „5" - zdecydowanie się do niej odnosi. Szczegółowy rozkład odpowiedzi prezentuje tabela 2.

Tabela 2. Ocena stresogenności wybranych cech pracy przedsiębiorcy

\begin{tabular}{|l|c|c|c|c|c|}
\hline \multicolumn{1}{|c|}{ Czynnik stresogenny } & Średnia & Mediana & Dominanta & $\begin{array}{c}\text { Liczność } \\
\text { mody }\end{array}$ & $\begin{array}{c}\text { Odchylenie } \\
\text { standardowe }\end{array}$ \\
\hline Konieczność pracy także w soboty & 3,37 & 3,00 & 3,00 & 58 & 1,00 \\
\hline $\begin{array}{l}\text { Praca wymagająca dużej koncentracji } \\
\text { uwagi }\end{array}$ & 4,03 & 4,00 & 4,00 & 76 & 0,86 \\
\hline Praca wymagająca dobrej pamięci & 3,84 & 4,00 & 4,00 & 73 & 0,85 \\
\hline $\begin{array}{l}\text { Konieczność rozwiązywania skompliko- } \\
\text { wanych problemów }\end{array}$ & 4,00 & 4,00 & 4,00 & 77 & 0,83 \\
\hline $\begin{array}{l}\text { Konieczność planowania działań długo } \\
\text { naprzód }\end{array}$ & 3,93 & 4,00 & 4,00 & 58 & 0,98 \\
\hline $\begin{array}{l}\text { Konieczność podejmowania decyzji finan- } \\
\text { sowych dotyczących spraw zawodowych }\end{array}$ & 4,09 & 4,00 & 4,00 & 63 & 0,90 \\
\hline Odpowiedzialność za majątek trwały & 4,17 & 4,00 & 5,00 & 69 & 0,87 \\
\hline $\begin{array}{l}\text { Odpowiedzialność za bezpieczeństwo } \\
\text { innych ludzi }\end{array}$ & 4,29 & 4,00 & 5,00 & 81 & 0,85 \\
\hline $\begin{array}{l}\text { Zaniedbania w wykonywanej pracy mogą } \\
\text { prowadzić do poważnych konsekwencji }\end{array}$ & 4,01 & 4,00 & 4,00 & 66 & 0,90 \\
\hline Konieczność podejmowania szybkich i & 3,96 & 4,00 & 4,00 & 63 & 0,94 \\
\hline
\end{tabular}

${ }^{23}$ Polska Agencja Rozwoju Przedsiębiorczości, Raport o stanie sektora matych $i$ średnich przedsiębiorstw w Polsce w latach 2011-2012, Warszawa 2013, http://badania.parp.gov.pl/files/74/81/626/18670.pdf, s. 23. 


\begin{tabular}{|l|c|c|c|c|c|}
\hline (lub) ryzykownych decyzji & & & & \\
\hline $\begin{array}{l}\text { Konieczność posiadania wysokich kwalifi- } \\
\text { kacji }\end{array}$ & 3,11 & 3,00 & 3,00 & 83 & 0,92 \\
\hline $\begin{array}{l}\text { Konieczność stałego uczenia się nowych } \\
\text { rzeczy }\end{array}$ & 3,54 & 4,00 & 4,00 & 52 & 1,04 \\
\hline $\begin{array}{l}\text { Konieczność bycia twórczym, pomysło- } \\
\text { wym }\end{array}$ & 3,57 & 4,00 & 3,00 & 49 & 1,06 \\
\hline $\begin{array}{l}\text { Praca wymagająca kontaktów z innymi } \\
\text { ludźmi }\end{array}$ & 3,65 & 4,00 & 5,00 & 53 & 1,27 \\
\hline $\begin{array}{l}\text { Praca wymagająca współpracy z urzędami, } \\
\text { instytucjami }\end{array}$ & 3,83 & 4,00 & 5,00 & 60 & 1,09 \\
\hline $\begin{array}{l}\text { Konieczność łamania przepisów, by wy- } \\
\text { pełnić swe zadania }\end{array}$ & 2,89 & 3,00 & 3,00 & 45 & 1,27 \\
\hline $\begin{array}{l}\text { Środowisko pracy jest miejscem konflik- } \\
\text { tów międzyludzkich }\end{array}$ & 3,25 & 3,00 & 3,00 & 68 & 0,99 \\
\hline
\end{tabular}

Źródło: opracowanie własne na podstawie wyników przeprowadzonych badań.

Spośród wymienionych cech pracy, które potencjalnie mogą mieć charakter stresogenny, badani wszystkie uznali za co najmniej w pewnym stopniu odnoszące się do pracy prywatnego przedsiębiorcy. Jedynie stwierdzenie, że wypełnienie zadań wymaga łamania przepisów uzyskało średnią poniżej $3,0(2,89)$, jednakże i w tym wypadku zarówno mediana, jak i wartość modalna wynoszą 3 .

Analizując wyniki, szczególną uwagę należy zwrócić na te itemy, gdzie mediana i moda wynosiły 4 lub 5. Zdaniem badanych stresorem w największym stopniu dotyczącym pracy przedsiębiorcy jest odpowiedzialność za bezpieczeństwo innych (średnia 4,29). Blisko połowa respondentów (moda 81) uznała go za zdecydowanie odnoszący się do pracy przedsiębiorcy. W niewiele mniejszym stopniu (średnia 4,17) za stresogenną badani uznali odpowiedzialność za majątek trwały. Jest to zrozumiałe, gdyż wielu przedsiębiorców odpowiada za prowadzoną działalność całym swoim majątkiem, a nie tylko majątkiem firmy (w zależności od formy prawnej przedsiębiorstwa). Za wysoce stresogenną badani studenci uznali też konieczność podejmowania decyzji finansowych związanych z prowadzoną działalnością $(4,09)$. We wszystkich trzech wypadkach należy zwrócić uwagę na wartość odchylenia standardowego - poniżej 1, co w praktyce oznacza, że spośród badanych nikt nie uznał tych stresorów za nieistotne w pracy przedsiębiorcy. Analizując treść kolejnych itemów, można zauważyć, że w opinii badanych praca przedsiębiorcy wymaga dużej koncentracji uwagi $(4,03)$, wszelkie zaniedbania w wykonywanej pracy mogą prowadzić do poważnych konsekwencji $(4,01)$, a przedsiębiorca na co dzień boryka się z koniecznością rozwiązywania skomplikowanych problemów $(4,00)$.

Stresorami, z którymi w mniejszym stopniu, ale także mogą się zetknąć przedsiębiorcy są zdaniem badanych: konieczność podejmowania działań niezgodnych z prawem $(2,89)$, posiadanie wysokich kwalifikacji $(3,11)$, narażenie na konflikty międzyludzkie $(3,25)$ oraz konieczność pracy także w soboty $(3,37)$.

Badani studenci różnili się między sobą wieloma cechami, które mogą wpływać na postrzeganie pracy przedsiębiorcy, jej wymagań i związanego z nią stresu. Należą do nich: kierunek studiów, ich stopień i tryb, tradycje rodzinne w zakresie prowadzenia działalności gospodarczej oraz płeć. Wyniki zawierają tabele $3-6^{24}$.

\footnotetext{
${ }^{24}$ We wszystkich tabelach uwzględniono tylko te itemy, w których zaobserwowano istotne statystycznie różnice.
} 
Tabela 3. Ocena stresogenności pracy przedsiębiorcy przez studentów kierunków zarządzanie (Z) i zarządzanie i inżynieria produkcji (ZiIP)

\begin{tabular}{|l|c|c|c|c|}
\hline \multicolumn{1}{|c|}{ Czynnik stresogenny } & \multicolumn{2}{|c|}{ Średnia } & \multirow{2}{*}{ t } & p \\
\cline { 2 - 4 } & $\mathbf{Z}$ & $\mathbf{Z i I P}$ & & \\
\hline Konieczność rozwiązywania skomplikowanych problemów & 4,190 & 3,897 & 2,176 & 0,031 \\
\hline Konieczność planowania działań długo naprzód & 4,172 & 3,804 & 2,348 & 0,020 \\
\hline $\begin{array}{l}\text { Konieczność podejmowania decyzji finansowych dotyczących spraw zawo- } \\
\text { dowych }\end{array}$ & 4,327 & 3,962 & 2,511 & 0,013 \\
\hline Odpowiedzialność za majątek trwały & 4,396 & 4,060 & 2,438 & 0,016 \\
\hline $\begin{array}{l}\text { Zaniedbania w wykonywanej pracy mogą prowadzić do poważnych konse- } \\
\text { kwencji }\end{array}$ & 4,327 & 3,841 & 3,406 & 0,001 \\
\hline Konieczność podejmowania szybkich i (lub) ryzykownych decyzji & 4,190 & 3,832 & 2,369 & 0,019 \\
\hline
\end{tabular}

Źródło: opracowanie własne na podstawie wyników przeprowadzonych badań.

Tabela 4. Ocena stresogenności pracy przedsiębiorcy przez studentów studiów I i II stopnia

\begin{tabular}{|c|c|c|c|c|}
\hline \multirow[b]{2}{*}{ Czynnik stresogenny } & \multicolumn{2}{|c|}{ Średnia } & \multirow[b]{2}{*}{$\mathbf{t}$} & \multirow[b]{2}{*}{$\mathbf{p}$} \\
\hline & $\begin{array}{l}\text { I sto- } \\
\text { pień }\end{array}$ & $\begin{array}{l}\text { II sto- } \\
\text { pień }\end{array}$ & & \\
\hline Konieczność rozwiązywania skomplikowanych problemów & 3,897 & 4,190 & 2,176 & 0,031 \\
\hline Konieczność planowania działań długo naprzód & 3,804 & 4,172 & 2,348 & 0,020 \\
\hline $\begin{array}{l}\text { Konieczność podejmowania decyzji finansowych dotyczących spraw } \\
\text { zawodowych }\end{array}$ & 3,962 & 4,327 & 2,510 & 0,013 \\
\hline Odpowiedzialność za majątek trwały & 4,056 & 4,396 & 2,438 & 0,016 \\
\hline $\begin{array}{l}\text { Zaniedbania w wykonywanej pracy mogą prowadzić do poważnych } \\
\text { konsekwencji }\end{array}$ & 3,841 & 4,327 & 3,406 & 0,001 \\
\hline Konieczność podejmowania szybkich i (lub) ryzykownych decyzji & 3,832 & 4,190 & 2,369 & 0,019 \\
\hline
\end{tabular}

Źródło: opracowanie własne na podstawie wyników przeprowadzonych badań.

Tabela 5. Ocena stresogenności pracy przedsiębiorcy przez studentów studiów stacjonarnych (St.) i niestacjonarnych (Nst.)

\begin{tabular}{|l|c|c|c|c|}
\hline \multicolumn{1}{|c|}{ Czynnik stresogenny } & \multicolumn{2}{|c|}{ Tryb } & \multirow{2}{*}{ t } & \multirow{2}{*}{ p } \\
\cline { 2 - 4 } & Nst. & St. & & \\
\hline Konieczność planowania działań długo naprzód & 4,134 & 3,796 & 2,213 & 0,028 \\
\hline $\begin{array}{l}\text { Konieczność podejmowania decyzji finansowych dotyczących spraw } \\
\text { zawodowych }\end{array}$ & 4,303 & 3,949 & 2,495 & 0,014 \\
\hline Odpowiedzialność za majątek trwały & 4,463 & 3,979 & 3,634 & 0,0003 \\
\hline Odpowiedzialność za bezpieczeństwo innych ludzi & 4,470 & 4,173 & 2,213 & 0,028 \\
\hline $\begin{array}{l}\text { Zaniedbania w wykonywanej pracy mogą prowadzić do poważnych konse- } \\
\text { kwencji }\end{array}$ & 4,328 & 3,796 & 3,871 & 0,0001 \\
\hline Praca wymagająca współpracy z innymi urzędami, instytucjami & 4,121 & 3,643 & 2,807 & 0,006 \\
\hline
\end{tabular}

Źródło: opracowanie własne na podstawie wyników przeprowadzonych badań.

Tabela 6. Ocena stresogenności pracy przedsiębiorcy przez studiujące kobiety i mężczyzn

\begin{tabular}{|c|c|c|c|c|}
\hline \multirow{2}{*}{ Czynnik stresogenny } & \multicolumn{2}{|c|}{ Srednia } & \multirow{2}{*}{$\mathbf{t}$} & \multirow{2}{*}{$\mathbf{p}$} \\
\hline & M & $\mathbf{K}$ & & \\
\hline Praca wymagająca dużej koncentracji uwagi & 3,762 & 4,196 & $-3,247$ & 0,001 \\
\hline $\begin{array}{l}\text { Konieczność rozwiązywania skomplikowanych proble- } \\
\text { mów }\end{array}$ & 3,778 & 4,137 & $-2,744$ & 0,007 \\
\hline Odpowiedzialność za bezpieczeństwo innych ludzi & 4,063 & 4,436 & $-2,780$ & 0,0066 \\
\hline
\end{tabular}

Źródło: opracowanie własne na podstawie wyników przeprowadzonych badań. 
Zgodnie z oczekiwaniami, cechy społeczno-demograficzne badanych różnicowały postrzeganą stresogenność pracy przedsiębiorcy. Zróżnicowanie to nie dotyczy jednak wszystkich ocenianych aspektów. Pracę przedsiębiorcy jako wymagającą dużej koncentracji uwagi akcentowały głównie kobiety $(4,196)$. Konieczność rozwiązywania skomplikowanych problemów to cecha, która była wyżej oceniana przez studentów kierunku zarządzanie $(4,189)$, studentów studiów II stopnia $(4,189)$ oraz kobiety $(4,137)$. Konieczność planowania działań długo naprzód w wyższym stopniu wskazywali studenci zarządzania $(4,172)$, studiów II stopnia $(4,172)$, trybu niestacjonarnego $(4,134)$. Podobny charakter miało zróżnicowanie dotyczące konieczności podejmowania decyzji finansowych odnoszących się do spraw zawodowych: studenci zarządzania $(4,327)$, II stopnia $(4,327)$, trybu niestacjonarnego $(4,303)$. Praca przedsiębiorcy to, zdaniem badanych, także duża odpowiedzialność. Poczucie to jest najwyższe wśród studentów zarządzania $(4,396)$, II stopnia $(4,396)$, studiów niestacjonarnych $(4,462)$. Ci ostatni $(4,469)$ oraz kobiety $(4,435)$ wskazywali również na wysoką odpowiedzialność za bezpieczeństwo innych ludzi. Blisko $\mathrm{z}$ tą cechą związane jest także poczucie, że zaniedbania w pracy mogą prowadzić do poważnych konsekwencji. Świadomość ta jest w większym stopniu udziałem studentów zarządzania $(4,327)$, II stopnia $(4,327)$, studiów niestacjonarnych $(4,328)$. Kolejną cechą pracy, w odniesieniu do której natężenia zaobserwowano pewne zróżnicowanie, była konieczność podejmowania szybkich i (lub) ryzykownych decyzji. Większe natężenie przybiera ona wśród studentów zarządzania $(4,189)$ i II stopnia $(4,189)$. Ostatnią cechą pracy, w której ocenie zaobserwowano zróżnicowanie, było stwierdzenie, że jest to praca wymagająca współpracy z innymi urzędami, instytucjami. Większe jej natężenie odnotowano $\mathrm{w}$ odniesieniu do studentów niestacjonarnych $(4,121)$. Łącznie badani studenci różnili się w ocenie stresogenności 9 z 17 analizowanych cech pracy przedsiębiorcy. W wypadku 5 cech zróżnicowanie dotyczyło trzech z pięciu analizowanych zmiennych (kierunek, stopień i tryb studiów). Co ciekawe, a nawet zaskakujące, zmienną, która w żadnej mierze nie różnicowała oceny badanych cech, okazały się tradycje rodzinne w zakresie przedsiębiorczości. Z kolei badając mity dotyczące przedsiębiorczości, badani najwyżej ocenili ten wskazujący, że przedsiębiorcy doświadczają ogromnych stresów i płaca ogromną cenę za swoje powodzenie $(3,92)$. Przy wysokiej ocenie w próbie wynik był zróżnicowany ze względu na tradycje przedsiębiorczości w rodzinie. Mit o stresogenności pracy przedsiębiorcy istotnie wyżej $(4,281 ; 3,717 ; \mathrm{p}<0,05)$ ocenili studenci, którzy nie mają tradycji rodzinnych w zakresie przedsiębiorczości.

Analiza związku między oceną poszczególnych czynników a postawą przedsiębiorczą, mierzoną zamiarem podjęcia działalności gospodarczej, wykazała, że jedynie w wypadku pierwszego z podanych itemów (konieczność pracy także w wolne soboty) istnieje wyraźna statystycznie różnica $-Z_{\text {popr. }}=2,204, p=0,0275$. Można więc stwierdzić, że dla badanej grupy studentów nie istnieje związek między oceną stresowości pracy przedsiębiorcy a postawą przedsiębiorcza.

Niewątpliwie każda praca, w tym praca prywatnego przedsiębiorcy, wiąże się ze specyficznymi stresorami. Z kolei powstaje pytanie, jakie cechy pracy przedsiębiorcy mogą pozytywnie wpływać na postawę wobec własnej działalności gospodarczej. Jednym $\mathrm{z}$ takich czynników może być relatywnie większe, w stosunku do pracy najemnej, poczucie kontroli. W omawianych badaniach podjęto próbę ustalenia, w jakim stopniu możliwość sprawowania stosunkowo większej kontroli nad własną pracą zachęca badanych studentów do podjęcia ,pracy na swoim”. Wyniki zaprezentowano w tabeli 7. 
Tabela 7. Czynniki zachęcające do podjęcia działalności

\begin{tabular}{|l|c|c|c|c|c|}
\hline \multicolumn{1}{|c|}{ Czynnik zachęcający } & Średnia & $\begin{array}{c}\text { Media } \\
\text { na }\end{array}$ & $\begin{array}{c}\text { Domi } \\
\text { nanta }\end{array}$ & $\begin{array}{c}\text { Licz } \\
\text { ność } \\
\text { mody }\end{array}$ & $\begin{array}{c}\text { Odchyle } \\
\text { nie standar- } \\
\text { dowe }\end{array}$ \\
\hline $\begin{array}{l}\text { Sam może decydować, kiedy podejmie dane } \\
\text { zadanie }\end{array}$ & 4,13 & 4,00 & Wielokrotna & 64 & 0,86 \\
\hline $\begin{array}{l}\text { Ma wpływ na sposób wykonywania (meto- } \\
\text { dy) realizowanych zadań }\end{array}$ & 4,15 & 4,00 & 4,00 & 70 & 0,80 \\
\hline $\begin{array}{l}\text { Ma możliwość decydowania o planach } \\
\text { swojej pracy }\end{array}$ & 4,21 & 4,00 & 5,00 & 69 & 0,83 \\
\hline $\begin{array}{l}\text { Ma wpływ na kształtowanie fizycznych } \\
\text { warunków pracy }\end{array}$ & 4,06 & 4,00 & 4,00 & 66 & 0,85 \\
\hline $\begin{array}{l}\text { Może według własnego uznania dobrać } \\
\text { swoich współpracowników }\end{array}$ & 4,24 & 4,00 & 5,00 & 75 & 0,85 \\
\hline
\end{tabular}

Źródło: opracowanie własne na podstawie wyników przeprowadzonych badań.

Przedstawione dane zdają się potwierdzać tezę o wysokim zakresie kontroli nad pracą jako czynniku zachęcającym do podejmowania działalności gospodarczej. Przy odchyleniu standardowym poniżej 1 pkt, każdy z wyszczególnionych czynników uzyskał średnią powyżej 4.0.

Z kolei analiza związku między oceną poszczególnych czynników a postawą przedsiębiorczą, mierzoną zamiarem podjęcia działalności gospodarczej, wykazała, że dla badanej grupy studentów w wypadku dwóch pierwszych czynników istnieje wyraźna statystycznie różnica:

- $\quad$ samodzielność decyzji o terminie podjęcia działania: $Z_{\text {popr. }}=2,468, p=0,014$;

- wpływ na sposób wykonywania realizowanych zadań: $Z_{\text {popr. }}=2,269, p=0,023$. $\mathrm{W}$ pozostałych wypadkach nie występują istotne statystycznie różnice.

\section{DYSKUSJA WYNIKÓW}

W omówionych badaniach przeanalizowano łącznie 17 cech pracy. Badani studenci dokonali oceny ich stresogenności w odniesieniu do pracy prywatnego przedsiębiorcy. Zdaniem badanych studentów praca ta jest w znacznej mierze stresująca (średnia 3,74 w skali 1-5). Warto przy tym zwrócić uwagę na te aspekty pracy, które oceniono jako najmniej i najbardziej stresujące. Do pierwszej kategorii można zaliczyć konieczność łamania przepisów, by wypełnić zadania $(2,89)$ i konieczność posiadania wysokich kwalifikacji $(3,11)$. Niewątpliwie na niskie średnie w tym zakresie wpływał kierunek studiów badanych. Innymi słowy, wydaje się wysoce prawdopodobne, że badani studenci dokonywali oceny przez pryzmat swoich kwalifikacji. Ponieważ wymagania w tym względzie nie przewyższają postrzeganych możliwości radzenia sobie z nimi, te aspekty pracy nie są postrzegane jako znaczące stresory. Za stresory w największym stopniu odnoszące się do pracy przedsiębiorcy badani uznali: odpowiedzialność za bezpieczeństwo innych osób i majątek trwały, konieczność podejmowania decyzji finansowych dotyczących spraw zawodowych, konieczność dużej koncentracji uwagi, poważne konsekwencje ewentualnych zaniedbań oraz konieczność rozwiązywania skomplikowanych problemów - średnie 
4,0 i powyżej. Są to stresory w znacznej mierze związane z treścią pracy i przyczyniające się do powstania konfliktu roli ${ }^{25}$.

Prywatny przedsiębiorca, oprócz licznych ograniczeń, ma też w swojej pracy znaczny zakres autonomii, i to ona jest istotnym czynnikiem, który potencjalnie mógłby zachęcić badanych do podjęcia własnej działalności. Wszystkie analizowane czynniki (5) uzyskały wysokie średnie, wynoszące powyżej 4 punktów.

Ocena stresogenności analizowanych aspektów pracy przedsiębiorcy jest zróżnicowana. Podobnie rzecz się ma, jeśli chodzi o ich ocenę przez poszczególne kategorie badanych. Studenci kierunków zarządzanie i inżynieria produkcji oraz zarządzanie, a także studiów stacjonarnych i niestacjonarnych istotnie statystycznie różnili się w ocenie stopnia stresogenności 6 cech pracy prywatnego przedsiębiorcy, kobiety i mężczyźni - w ocenie 3 cech, a osoby o odmiennych postawach przedsiębiorczych (planujące i nieplanujące podjęcia własnej działalności) - zaledwie 1 cechy. $\mathrm{Z}$ punktu widzenia niniejszych badań szczególnie istotny jest ostatni wynik, który w zasadzie nie potwierdza przyjętych założeń o związku pomiędzy oceną stresogenności pracy przedsiębiorcy a postawami przedsiębiorczymi. Z jednej strony może to być związane ze specyfiką grupy badawczej, którą w tym kontekście trudno uznać za reprezentatywną. Z drugiej strony zaś końcowa ocena stresu w pracy przedsiębiorcy jest wypadkową oceny związanych z nią wymagań i zakresu kontroli. Rację wreszcie może mieć Beata Basińska, pisząc, że „Koncepcje stresu pracy odwołujące się przede wszystkim do identyfikacji źródeł mają coraz mniejsze znaczenie w wyjaśnianiu zjawiska stresu. Ich zasługa jest dobre zrozumienie złożoności środowiska i warunków pracy oraz możliwość jego reorganizacji. Należy jednak pamiętać, że wraz ze zmianami zachodzącymi na rynku pracy, pojawiają się nowe stresory”, ${ }^{26}$. Dlatego też warto kontynuować badania w tym względzie, z jednej strony poszerzając próbę badawcza, z drugiej zaś testując przydatność innych koncepcji stresu.

Wysoka ocena stresogenności pracy przedsiębiorcy wśród badanych wiązała się również z postrzeganiem tej formy zarobkowania jako swego rodzaju wyzwania, możliwości daleko idącej kreacji własnej rzeczywistości zawodowej. Wszystkie wymienione w ankiecie czynniki zachęcające do podjęcia własnej działalności uzyskały średnie powyżej 4,0. Przy tak wysokich ocenach nie zaobserwowano istotnego statystycznie zróżnicowania wyników. Jedyną zmienną w wypadku dwóch czynników okazały się postawy przedsiębiorcze. Być może dalsza eksploracja $\mathrm{w}$ tym zakresie pozwoli na potwierdzenie przyjętego założenia o zakresie kontroli jako cesze sprzyjającej postawom przedsiębiorczym. Na zakończenie warto podkreślić, że opisane badania miały charakter pilotażowy, przez co wyciągnięte na ich podstawie wnioski mają ograniczony charakter. Pozwalają jednak jak się wydaje - na dokonanie korekty przyjętych założeń i pogłębienie analiz wybranych obszarów.

\section{LITERATURA}

[1] Basińska B., Postprint, Warunki pracy a źródta stresu właścicieli matych przedsiębiorstw, [w:] Humanizacja wobec wyzwań transformacyjnych i cywilizacyjnych, red. D. Walczak-Duraj, Wydawnictwo Naukowe Novum, Płock 2005.

\footnotetext{
${ }^{25}$ Analogiczne wyniki uzyskała w swoich badaniach B. Basińska. Por. B. Basińska, Postprint, Warunki pracy a źródta stresu wtaścicieli matych przedsiębiorstw, [w:] Humanizacja wobec wyzwań transformacyjnych $i$ cywilizacyjnych, red. D. Walczak-Duraj, Wydawnictwo Naukowe Novum, Płock 2005.

${ }^{26}$ Ibidem, s. 10.
} 
[2] Bławat F., Przedsiębiorca w teorii przedsiębiorczości i praktyce małych firm, Gdańskie Towarzystwo Naukowe, Gdańsk 2003.

[3] Cieślak R., Widerszal-Bazyl M., Psychospołeczne warunki pracy. Podręcznik do kwestionariusza, CIOP, Warszawa 2000.

[4] Czarnik S., Turek K., Wyksztatcenie, praca, przedsiębiorczość Polaków. Na podstawie badań zrealizowanych w 2012 roku w ramach III edycji projektu Bilans Kapitatu Ludzkiego, Polska Agencja Rozwoju Przedsiębiorczości, Warszawa 2012.

[5] Europejska Agencja Bezpieczeństwa i Zdrowia w Pracy, Badania nad stresem w pracy, Luksemburg 2006.

[6] Jachnis A., Psychologia organizacji. Kluczowe zagadnienia, Difin, Warszawa 2008.

[7] Kurczewska A., Przedsiębiorczość jako proces współoddziaływania sposobności i intencji przedsiębiorczych, PWN, Warszawa 2013.

[8] Laszczak M., Kierowanie mata firmq. Tajniki przedsiębiorczości, Poltext, Warszawa 2004.

[9] Marody M., Sens teoretyczny a sens empiryczny pojęcia postawy. Analiza metodologiczna zasad doboru wskaźników w badaniach nad postawami, PWN, Warszawa 1976.

[10] Mikroprzedsiębiorstwa: sytuacja ekonomiczna, finansowanie, wtaściciele, red. E. Balcerowicz, CASE-Centrum Analiz Społeczno-Ekonomicznych, Warszawa 2002.

[11] Piecuch T., Przedsiębiorczość. Podstawy teoretyczne, C.H. Beck, Warszawa 2010.

[12] Polska Konfederacja Pracodawców Prywatnych LEWIATAN, Przedsiębiorcy w Polsce. Fakty, liczby, przykłady, Warszawa 2012.

[13] Rathus S.A., Psychologia wspótczesna, tłum. B. Wojciszke, Gdańskie Wydawnictwo Psychologiczne, Gdańsk 2004.

[14] Robbins S.P., DeCenzo D.A., Podstawy zarzadzania, PWE, Warszawa 2002.

[15] Wojciszke B., Człowiek wśród ludzi. Zarys psychologii społecznej, Wydawnictwo Naukowe SCHOLAR, Warszawa 2002

[16] Schwarz E.J., Wdowiak M.A., Almer-Jarz D.A., Breitenecker R.J., The effects of attitudes and perceived environment conditions on students' entrepreneurial intent. An Austrian perspective, ,Education + Training” 51/4 (2009).

[17] Zimbardo P.G., Leippe M.R., Psychologia zmiany postaw i wptywu spotecznego, thum. P. Kwiatkowski, Zysk i S-ka, Poznań 2004.

\section{Źródła internetowe}

[1] http://www.stat.gov.pl/cps/rde/xbcr/gus/f_polska_w_liczbach_2012.pdf

[2] Polska Agencja Rozwoju Przedsiębiorczości, Raport o stanie sektora matych i średnich przedsiębiorstw w Polsce za lata 2011-2012, Warszawa 2013, http://www.parp.gov.pl/ index/more/37123

[3] http://www.zus.pl/files/dpir/20081201_Ocena_obciazenia_zal2.pdf

\section{STUDENTS' EVALUATION ON THE STRESS MADE BY WORKING AS EN- TREPRENEUR. PILOT STUDY RESULTS}

The article presented selected results of pilot studies, which focused on entrepreneurial attitudes of students. In this paper, the focus has been placed on the perception of entrepreneurs working as a factor that could shape the intention to take their own business. The adopted by the authors of the research model assumed that the emergence of entrepreneurial intentions are influenced by a variety of factors. One of them is the perception of future work. As factors that could potentially shape the entrepreneurial attitude adopted stress-made of the actions taken by the entrepreneur and the scope of the job audit. As one of the main objectives of the study were adopted to assess the extent stress and the identification of the relationship between the assessment, and 
the evolution of entrepreneurial attitudes, measured by the entrepreneurial intention. An additional aim was also to assess the impact of job audit's scope on the presented entrepreneurial intentions. The results that were obtained in the effect of the pilot indicate that a test group of students all of the features mentioned working entrepreneurs have the potential nature of the stressor, but this is not significant from the point of view presented by their entrepreneurial attitudes. The conducted study also found that respondents high range of the job audit's scope of an entrepreneur as a stimulus to take in the future business. However, also in this case, only two of the five test factors differentiating variable proved to be entrepreneurial attitudes.

Keywords: stress at work, job decision latitude, entrepreneurial attitudes, entrepreneurship

\section{DOI: $10.7862 /$ rz.2014.mmr.60}

Tekst złożono w redakcji: listopad 2014

Przyjęto do druku: grudzień 2014 